\title{
MALIGNANCY IN AN AMPUTATED LEG STUMP - A RARE CASE
}

Karigalan. K, Haripriya Reddy

1. Assistant Professor, M. S. Department of General Surgery, P. E. S. I. M. S. R, Kuppam, Andhra Pradesh.

2. Assistant Professor, M. S. Department of General Surgery, P. E. S. I. M. S. R, Kuppam, Andhra Pradesh.

\section{CORRESPONDING AUTHOR}

Dr. Karigalan K.

No. 202, II Floor, Staff Quarters,

P. E. S. I. M. S. R.

E-mail: drkarigalan@gmail.com,

Ph: 0091900767648.

ABSTRACT: Amputation of lower extremity followed by use of leg prosthesis is very common. However, malignancy arising in the amputation stump is extremely rare. We are reporting such a case in a 52-year-old man. Review of the English literature reveals only five additional cases occurring in men with an average age of 65 years and after a mean lag period of 40 years between the amputation and development of a low-grade squamous cell carcinoma.

KEYWORDS: Malignancy in amputation stump; Squamous cell carcinoma; Leg prosthesis. MESH TERMS: Amputation Stumps; Carcinoma, squamous cell; Artificial Limbs

INTRODUCTION: Amputation of the leg followed by the use of artificial leg is very common. However, a malignant tumor arising in an amputation stump remains a very rare occurrence. The purpose of this paper is to report a case of squamous cell carcinoma arising in an amputation stump with a review of all other 5cases of malignancy arising in stumps published in the English literature.

CASE REPORT: A 52year old man sustained crush injury to left lower limb in a train accident 25 years back.

He underwent left above knee amputation and was fitted with an artificial limb. He had continued difficulty with proper fitting of the prosthesis over the years. Almost 25 years later, the patient started experiencing increased pain at the amputation site and noted foul smelling discharge from the area. The skin over the distal stump was macerated, ulcerated with purulent foul smelling exudate. He was managed in the wound care clinic with wound cleaning and antibiotics over the last 6months. During that period, the distal stump area developed a fungating tissue that bleeds on touch. He was unable to use the leg prosthesis. He is a known case of diabetes, taking treatment.

The amputated stump showed an irregular ulcer of $10 \mathrm{~cm} x 10 \mathrm{~cm}$ with an exophytic growth of $6 \mathrm{~cm}$ in its largest dimension. Ulcer had raised, everted edges that bleed easily on touch and an indurated base with foul smelling discharge (Fig.11). No inguinal lymphadenopathy, no evidence of metastatic spread seen.

Patient underwent a left above knee revision amputation with wide local excision of tumour margins. Specimen was sent for histopathological examination. Postoperative period was uneventful and patient was discharged on $10^{\text {th }}$ postop day after suture removal.

Microscopically, well formed keratin pearls, stromal infiltration with lymphocytes and resected margins free of tumour cells were noted (Fig.2). Hence histopathology report notified features suggestive of well-differentiated type of squamous cell carcinoma.

Journal of Evolution of Medical and Dental Sciences/Volume1/Issue5/November-2012Page-730 
DISCUSSION: Cutaneous carcinomata of the lower extremities seem to be never a primary condition [1]. About 60,000 leg amputations are performed each year in the United States. These patients are usually fitted with leg prosthesis. The distal aspect of the stump has the scar from surgical closure. Whereas malignant tumor, commonly a squamous cell carcinoma is known to occur in scarred tissue from burn, chronic ulcers, wounds, sinus and fistulous tracts $[\underline{2} \underline{3}]$, the occurrence of cancer in amputated leg stump is very rare.

The earliest report of a stump carcinoma that we could find in the English literature was in 1965 describing a 75-year -old white man who had undergone a left above the knee amputation following a railroad accident [4]. He was fitted with leg prosthesis. Forty-seven years later, the patient developed a well-differentiated squamous cell carcinoma at the amputation stump scar. He underwent a high thigh amputation and inguinal lymph node dissection. There were no metastases.

In 1985, a case of a 60-year-old man who developed a low-grade squamous cell carcinoma on the below-the-knee amputation stump was reported [ $\underline{5}$ ]. The patient had undergone amputation of his leg 30 years earlier because of traumatic injury and burn suffered in a dynamite explosion. He used an artificial leg since then. The patient developed the cancer in the burn scar rather than in the scar of stump closure. He was treated with above-knee amputation. There was no evidence of metastatic spread.

In 1991, there were two reports of carcinoma arising in leg amputation stump [ㅁ, $\underline{7}$ ] In one report [6], a 56 -year -old man developed a rapidly growing squamous cell carcinoma at the end of his right below-knee amputation stump 27 years after his leg was amputated for gangrene from a snake-bite injury. He was using a poorly constructed prosthesis. The tumor was widely excised. The carcinoma arose in the scar tissue of the stump. There was no distant spread. The other case [7] was that of a 65-year- old man who developed a verrucous squamous cell carcinoma at the stump about 45 years after he underwent a traumatic below-the-knee amputation followed by use of leg prosthesis. The tumor was locally excised with a revision of the amputation.

The latest report of a carcinoma arising in an amputation stump was that of a 62-yearold man who developed a well-differentiated squamous cell carcinoma on his right thigh amputation stump 52 years after the procedure []]. The amputation was performed because of a land mine injury. He was using a leg prosthesis ever since. The patient underwent a surgical revision of the amputation stump and inguinal lymph node dissection. There was no metastatic spread.

Malignancy occurring in leg amputation stump remains a rare event as evidenced by only six such reported cases (including the present case) in the English literature since 1965.All the patients were male, aged 56 to 75 years with a mean age of 63 years. Amputation was done mostly for trauma $[\underline{4}, \underline{5}, \underline{7}, \underline{8}]$. In two cases $[\underline{5}, \underline{6}]$, burn from dynamite and mine explosion was an additional factor. The time between the amputation and the development of malignancy at the stump ranged from 27 to 52 years with a mean lag period of 40 years. All patients developed low-grade squamous cell carcinoma, of which two patients showed a verrucous type of squamous cell carcinoma.

The factors that may lead to malignancy at a stump may include long-standing scar tissue and burn injury. Patients who underwent amputation at an older age may not live long enough to develop stump carcinoma because the average lag period of developing such a lesion is 40 years. The patients who have undergone amputation at a younger age may have a small risk of developing malignancy at the stump over their lifetime.

Journal of Evolution of Medical and Dental Sciences/Volume1/Issue5/November-2012Page-731 
Neoplasms associated with scars and chronic ulcers are well documented for humans. These lesions comprise approximately $2 \%$ of all human epidermal neoplasms. Squamous cell carcinoma is the most common tumor and typically occurs 20 to $40 \mathrm{y}$ after the initial injury. Rarely, the original wound does not heal, and a neoplasm appears within a relatively short time ( 3 to $12 \mathrm{mo}$ ). These neoplasms are termed "acute wound cancers," since they appear relatively rapidly compared with other scar-associated neoplasms [ㅁ]

Carcinoma arising from scar, accounts for $0.78 \%$ of all inpatients with scars and $17 \%$ of all skin carcinoma patients. Scar carcinoma is a highly differentiated squamous cell carcinoma in most of the cases. Because of scar fibrosis and thrombosis of blood vessel and lymphatic vessel, the growth of scar carcinoma is slow. The metastasis is restricted. If the carcinoma can be diagnosed and treated early, the prognosis is favourable. The principle of operation is wide

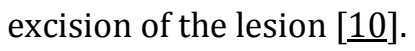

The clinical appearance of skin metastases varies over a wide morphologic spectrum, cutaneous metastases mimicking herpes zoster being rare. zosteriform cutaneous metastases secondary to a squamous cell carcinoma (SCC) which developed in the stump of an amputated arm is reported. The pathogenesis is speculative, but the zosteriform distribution might well be explained by perineural lymphatic invasion and spread [11].

Marjolin's ulcers are uncommon malignancies arising from previously traumatized, chronically inflamed or scarred skin. They are usually squamous cell carcinomas and they may present decades after the original insult. Marjolin's ulcers may occur on stumps in patients using prostheses, in this situation the diagnosis may be delayed because of the false assumption that the ulcer is caused by an ill fitting prosthesis [12]. A high index of suspicion is required in the management of chronic non-healing ulcers and all suspected lesions should be biopsied [13]. The squamous cell carcinoma of Marjolin's ulcer has the worst prognosis in comparison with other squamous cell carcinomas and it requires an aggressive treatment [14].

Epithelioma cuniculatum (EC) belongs to the category of verrucous carcinomas. Invasiveness and rate of metastasis are low, but there is a high risk of local recurrence. In cases of long-standing processes with formation of exophytic, malodorous tumors with jagged edges that do not respond to conventional therapy, consideration should already be given to EC upon visual inspection. The diagnosis is always established by histological examination. The standard treatment of EC is extensive excision of the tumor with micrographic margin control [15].

\section{REFERENCES:}

1. De Asis C. CUTANEOUS CARCINOMA OF THE LOWER EXTREMITIES: A STUDY OF CASES AT THE BARNES AND THE BARNARD FREE SKIN AND CANCER HOSPITALS OF ST. LOUIS, MO. Ann Surg. 1926 May;83(5):663-81.

2. Arons MS, Lynch JB, Lewis SR, Blocker TG. Scar tissue carcinoma. Part 1. A clinical study with special reference to burn scar carcinoma. Ann Surg 1965; 161:170-188.

3. Bartle EJ, Sun JH, Wang XW, Schneider BK. Cancers arising from burn areas. A literature review of twenty-one cases. J Burn Care Rehab 1990; 11:46-49.

4. Wilhite JL. Carcinoma developing in a pre-existing scar. A case report of carcinoma of amputation stump. Va Med Mon 1964; 91: 292-294.

5. Sarma D, Weilbaecher TG. Carcinoma arising in burn scar. J Surg Oncol 1985; 29:89-90.

6. Mahaisavariya B, Mahaisavariya. Marjolin's ulcer complicating a poorly fabricated prosthesis. Injury 1991; 22: 423-424.

Journal of Evolution of Medical and Dental Sciences/Volume1/Issue5/November-2012Page-732 
7. Schwartz RA, Bagley MP, Janniger CK, Lambert WC. Verrucous carcinoma of a leg amputation stump. Dermatologica 1991; 182: 193-195.

8. Karakozis S, Stamou SC, He P, Smookler B, Caceres M. Carcinoma arising in an amputation stump. Am Surg 2001; 67: 495-497.

9. Kathleen Rogers, George M. Barrington, Steven M. Parish. The Canadian Veterinary Journal. 1997 Oct; 38(10)643-644

10. Ji ZL. [Skin carcinoma arising from scar (a report of 6 cases)]. Zhonghua Zheng Xing Shao Shang Wai Ke Za Zhi. 1993 Nov;9(6):428-30, 478. Chinese. PubMed PMID: 8149290.

11. Cuq-Viguier L, Viraben R. Zosteriform cutaneous metastases from squamous cell carcinoma of the stump of an amputated arm. Clin Exp Dermatol. 1998 May;23(3):116-8. PubMed PMID: 9861739.

12. Bloemsma GC, Lapid O. Marjolin's ulcer in an amputation stump. J Burn Care Res. 2008 Nov-Dec;29(6):1001-3. PubMed PMID: 18849841.

13. Chalya PL, Mabula JB, Rambau P, Mchembe MD, Kahima KJ, Chandika AB, Giiti G, Masalu N, Ssentongo R, Gilyoma JM. Marjolin's ulcers at a university teaching hospital in Northwestern Tanzania: a retrospective review of 56 cases. World J Surg Oncol. 2012 Feb 15;10:38. PubMed PMID: 22336561; PubMed Central PMCID: PMC3292918.

14. Shahla A. An overview of heel Marjolin's ulcers in the Orthopedic Department of Urmia University of Medical Sciences. Arch Iran Med. 2009 Jul;12(4):405-8. PubMed PMID: 19566359.

15. Weberschock T, Flux K, Gholam P, Hartschuh W, Hartmann M. [Verrucous tumor of the amputation stump]. Hautarzt. 2010 Mar;61(3):250-4. German. PubMed PMID: 20127299.

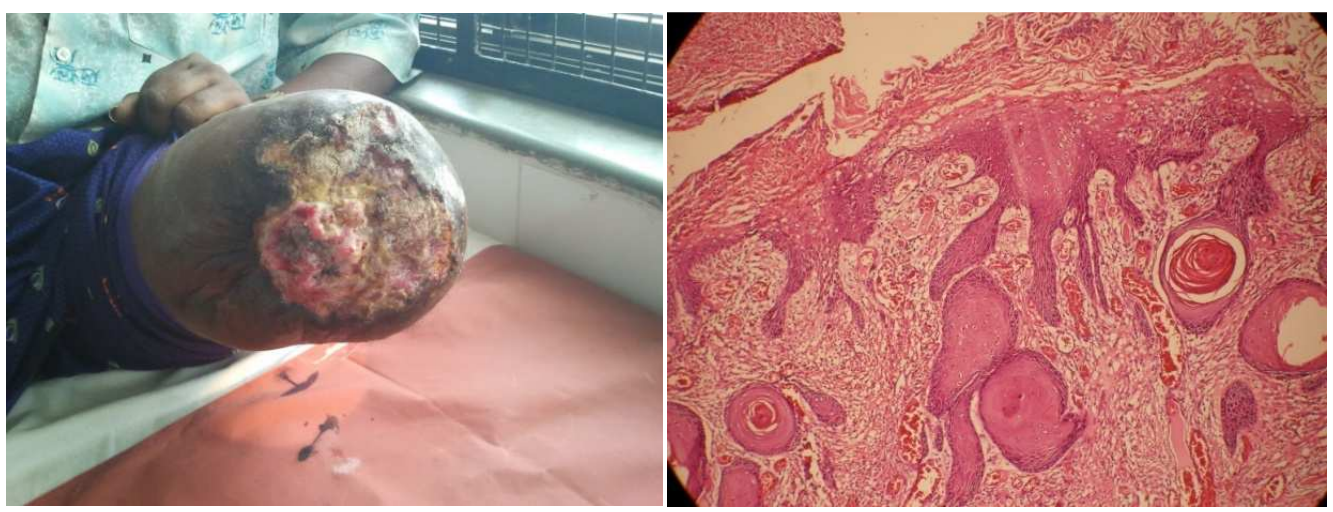

Fig.1 Irregular ulcer with exophytic growth Fig.2 Well-differentiated squamous cell carcinoma 